\title{
Effect of Zinc-Cadmium Interactions on the Uptake of Zinc and Cadmium by Winter Wheat (Triticum aestivum) Grown in Pot Culture
}

Y. G. Zhu, ${ }^{1}$ Z. Q. Zhao, ${ }^{1}$ H. Y. Li, ${ }^{2,3}$ S. E. Smith, ${ }^{3}$ F. A. Smith ${ }^{3}$

1 Department of Soil Environmental Sciences, Research Center for Ecoenvironmental Sciences, Chinese Academy of Sciences, Beijing 100085, People's Republic of China

2 Institute of Genetics and Developmental Biology, Chinese Academy of Sciences, Shijiazhuang, People's Republic of China

3 Department of Soil and Water, The University of Adelaide, Glen Osmond 5064, Australia

Received: 31 August 2002/Accepted: 7 October 2003

Cadmium $(\mathrm{Cd})$ is a non-essential element with no beneficial effects on plants, and is generally considered as a toxic contaminant in food for humans and animal feed (McLaughlin and Singh 1999). The accumulation of $\mathrm{Cd}$ in edible parts of crop plants is increasingly becoming a public health issue in many nations (Jin et al. 2002). Soil contamination by $\mathrm{Cd}$ is due to both natural and anthropogenic sources. Anthropogenic sources include the application of chemical fertilizers and pesticides, irrigation with Cd-contaminated wastewater, atmospheric deposition and the application of sewage sludge in arable land. At Rothamsted in England, increases in $\mathrm{Cd}$ concentrations in wheat grain from 50 to $80 \mu \mathrm{g} \mathrm{kg}-1$ between 1880 and 1980 were attributed to the use of chemical fertilizers (Jones and Johnston 1989). Cd can be easily transferred via food-chains and accumulated in human bodies. Typical health problems resulting from excessive body burden of $\mathrm{Cd}$ include: renal dysfunction, liver damage, lung edema, anemia and hypertension (Basta, et al. 1998).

Unlike $\mathrm{Cd}$, zinc $(\mathrm{Zn})$ is an essential element both for plants and humans, but if present in high concentration in plants and humans it can also be highly toxic. While $\mathrm{Zn}$ deficiency is a widespread problem in calcareous soils in many parts of the world, $\mathrm{Zn}$ contamination can be a serious problem in areas near mining and smelting industries or long-term application of sewage sludge. It is generally accepted that $\mathrm{Zn}$ status in soils and plants plays an important role in $\mathrm{Cd}$ accumulation in crop plants. Oliver et al. (1994) demonstrated that application of $\mathrm{Zn}$ to wheat grown on marginally or severely $\mathrm{Zn}$-deficient soils in South Australia 
decreased $\mathrm{Cd}$ concentration in grain by up to $50 \%$. Other studies showed that $\mathrm{Zn}$ application could reduce Cd accumulation in flax seeds (Grant and Bailey 1997) and durum wheat grain (Choudhary et al. 1994). However, other studies showed that there was no interaction or even synergism between $\mathrm{Zn}$ and $\mathrm{Cd}$ (Williams and David 1976; White and Chaney 1980).

Most of the studies on the uptake of $\mathrm{Cd}$ by plants have been made in isolation, without considering $\mathrm{Cd}$ co-existence with other contaminants, such as $\mathrm{Zn}$. However, in many actual field situations, soil environments are often contaminated with multiple heavy metals, such as $\mathrm{Cd}, \mathrm{Zn}, \mathrm{Pb}$, etc. In such cases, these metal ions will interact with each other, affecting the fate of each metal in soil-plant systems. The aim of the present study was therefore to investigate the interactions between $\mathrm{Zn}$ and $\mathrm{Cd}$ under wide range of soil $\mathrm{Zn}$ concentrations from adequacy to contamination levels.

\section{MATERIALS AND METHODS}

This study was a pot experiment with a loamy soil (originally $0-25 \mathrm{~cm}$ depth) from the Luancheng Experimental Station, Chinese Academy of Sciences (CAS), Shijiazhuang. The soil was air dried and sieved ( $<2 \mathrm{~mm}$ stainless steel mesh) prior to analysis of its chemical properties (Table 1). The soil was amended to give four levels of Cd: 0, 15, 30 and $50 \mathrm{mg} \mathrm{kg}^{-1}$, and five levels of $\mathrm{Zn}: 0,2,10,100$ and 1000 $\mathrm{mg} \mathrm{kg}{ }^{-1}$. Thus, there were 20 treatments altogether. Zinc was supplied as zinc sulphate and cadmium was supplied as cadmium chloride. There was uniform application of N-P-K fertilizer at amounts equal to $200 \mathrm{mg} \mathrm{N} \mathrm{kg}^{-1}$ soil (added as urea), $133 \mathrm{mg} \mathrm{P}_{2} \mathrm{O}_{5} \mathrm{~kg}^{-1}$ (added as $\mathrm{CaHPO}_{4}$ ) and $133 \mathrm{mg} \mathrm{K}_{2} \mathrm{O} \mathrm{kg}^{-1}$ (added as $\mathrm{K}_{2} \mathrm{SO}_{4}$ ). Each treatment had three replicates.

The treated soils were mixed thoroughly, put into plastic pots $(1 \mathrm{~kg} / \mathrm{pot})$ and saturated with deionized water. Soil was allowed to equilibrate in the greenhouse for one week before sowing the seeds. Six germinated seeds of winter wheat (Triticum aestivum, L.), Kenong. 9204, (from Institute of Genetics and Developmental Biology, CAS, Shijiazhuang, China), were planted in each pot. The pots were randomly arranged in a greenhouse and rearranged several times during the growth period. When the seedlings had grown to about $3 \mathrm{~cm}$, they were thinned to three per pot. The seedlings were irrigated with deionized water every three days. The growth temperature was $18^{\circ} \mathrm{C}$ on average during $14 / 10 \mathrm{~h} \mathrm{light/dark} \mathrm{cycles.} \mathrm{The}$ plants were harvested after nine weeks.

The plants were separated into shoots and roots and rinsed thoroughly with deionized water, and the fresh weights were determined. The samples were then 
oven dried at $70^{\circ} \mathrm{C}$ for $48 \mathrm{~h}$, and the dry weight of shoots and roots were recorded. Dried plant samples were finely ground in a stainless steel mill.

Sub-samples $(0.25 \mathrm{~g})$ of finely ground plant materials were digested at $160^{\circ} \mathrm{C}$ in $5 \mathrm{ml}$ high-purity mixed acid $\left(\mathrm{HNO}_{3}: \mathrm{HClO}_{4}=6: 1\right)$. The digest was diluted to $50 \mathrm{ml}$ using high-purity water, and the concentrations of $\mathrm{Cd}$ in the solution were determined by ICP-MS (Inductively Coupled Plasma Mass Spectrometry, Agilent 7500a, USA).

All data were subjected to analysis of variance (ANOVA) using commercially available GENSTAT ( $6^{\text {th }}$ ed., NAG Ltd, England)

\section{RESULTS AND DISCUSSION}

The chemical properties of the soil used in this experiment were summarized in table 1 .

Table 1. Selected chemical properties of the soil used in the pot experiment

\begin{tabular}{cccccccc}
\hline $\mathrm{pH}$ & $\begin{array}{c}\text { OM } \\
\%\end{array}$ & $\begin{array}{c}\text { Available } \\
\mathrm{N} \\
\mathrm{mg} \mathrm{kg}^{-1}\end{array}$ & $\begin{array}{c}\text { Available } \\
\mathrm{P} \\
\mathrm{mg} \mathrm{kg}^{-1}\end{array}$ & $\begin{array}{c}\text { Available } \\
\mathrm{Kg} \mathrm{kg}\end{array}$ & $\begin{array}{c}\text { CEC } \\
\mathrm{cmol} / \mathrm{kg} \\
(+)\end{array}$ & $\begin{array}{c}\text { Tot. Zn } \\
\mathrm{mg} \\
\mathrm{kg}^{-1}\end{array}$ & $\begin{array}{c}\text { Tot. Cd } \\
\mathrm{mg} \\
\mathrm{kg}^{-1}\end{array}$ \\
\hline 7.7 & 1.4 & 80.0 & 24.1 & 198.7 & 10.0 & 176.6 & 0.1 \\
\hline
\end{tabular}

Table 2. Shoot biomass ( $\mathrm{g}_{\text {pot }}{ }^{-1}$ ) of winter wheat plants grown in pot culture with different additions of $\mathrm{Cd}$ and $\mathrm{Zn}$.

\begin{tabular}{llllll}
\hline $\begin{array}{l}\text { Cd addition } \\
\mathrm{mg} \mathrm{kg}{ }^{-1} \text { soil }\end{array}$ & \multicolumn{5}{c}{ Zn addition (mg kg soil) } \\
\hline & 0 & 2 & 10 & 100 & 1000 \\
\hline 0 & $2.89 \pm 0.11$ & $2.93 \pm 0.06$ & $3.09 \pm 0.04$ & $2.58 \pm 0.04$ & $0.23 \pm 0.01$ \\
15 & $2.34 \pm 0.05$ & $2.40 \pm 0.07$ & $2.35 \pm 0.05$ & $2.42 \pm 0.04$ & $0.24 \pm 0.01$ \\
30 & $1.31 \pm 0.03$ & $1.43 \pm 0.05$ & $1.63 \pm 0.03$ & $1.62 \pm 0.06$ & $0.24 \pm 0.01$ \\
50 & $1.32 \pm 0.06$ & $1.23 \pm 0.03$ & $1.25 \pm 0.07$ & $1.02 \pm 0.04$ & $0.23 \pm 0.02$ \\
\hline \multicolumn{5}{c}{ Analysis of variance } \\
\hline $\mathrm{Cd}$ & \multicolumn{5}{c}{$\mathrm{P}<0.001$} \\
$\mathrm{Zn}$ & $\mathrm{P}<0.001$ & \\
$\mathrm{Cd} \times \mathrm{Zn}$ & & $\mathrm{P}<0.001$ & \\
\hline
\end{tabular}

At any level of $\mathrm{Zn}$ addition up to and including $100 \mathrm{mg} \mathrm{kg}$, shoot biomass decreased significantly with $\mathrm{Cd}$ addition (Table 2); shoot biomass with $50 \mathrm{Cd} \mathrm{mg}$ $\mathrm{kg}^{-1}$ was at most $50 \%$ of that with no added $\mathrm{Cd}$. Application of $0-100 \mathrm{mg} \mathrm{Zn} \mathrm{kg}^{-1} \mathrm{did}$ not significantly affect shoot biomass, but $1000 \mathrm{mg} \mathrm{Zn} \mathrm{kg}^{-1}$ caused sharp decreases. Root biomass showed very similar pattern of changes as shoot biomass, with the 
exception of the treatment with $50 \mathrm{mg} \mathrm{Cd}$ plus $1000 \mathrm{mg} \mathrm{Zn} \mathrm{kg}{ }^{-1}$, in which root biomass was reduced compared with the treatment with $0 \mathrm{Cd}$ plus $1000 \mathrm{mg} \mathrm{Zn} \mathrm{kg}^{-1}$ (Table 3).

Table 3. Root biomass $\left(\mathrm{g} \mathrm{pot}^{-1}\right)$ of winter wheat plants grown in pot culture with different additions of $\mathrm{Cd}$ and $\mathrm{Zn}$.

\begin{tabular}{llllll}
\hline $\begin{array}{l}\text { Cd addition } \\
\mathrm{mg} \mathrm{kg}^{-1} \text { soil }\end{array}$ & \multicolumn{5}{c}{$\mathrm{Zn}$ addition $\left(\mathrm{mg} \mathrm{kg}^{-1}\right.$ soil) } \\
\hline & 0 & 2 & 10 & 100 & 1000 \\
\hline 0 & $1.13 \pm 0.05$ & $1.06 \pm 0.05$ & $1.06 \pm 0.03$ & $0.99 \pm 0.05$ & $0.13 \pm 0.01$ \\
15 & $0.92 \pm 0.05$ & $0.82 \pm 0.07$ & $0.84 \pm 0.02$ & $0.86 \pm 0.01$ & $0.15 \pm 0.01$ \\
30 & $0.51 \pm 0.03$ & $0.49 \pm 0.01$ & $0.54 \pm 0.02$ & $0.62 \pm 0.02$ & $0.17 \pm 0.02$ \\
50 & $0.51 \pm 0.04$ & $0.51 \pm 0.03$ & $0.51 \pm 0.04$ & $0.47 \pm 0.02$ & $0.09 \pm 0.01$ \\
\hline \multicolumn{5}{c}{ Analysis of variance } \\
\hline $\mathrm{Cd}$ & \multicolumn{5}{c}{$\mathrm{P}<0.001$} \\
$\mathrm{Zn}$ & $\mathrm{P}<0.001$ & \\
$\mathrm{Cd} \times \mathrm{Zn}$ & & $\mathrm{P}<0.001$ & \\
\hline
\end{tabular}

With no $\mathrm{Cd}$ addition, $\mathrm{Cd}$ concentrations in shoots were undetectable. This is due to the low background $\mathrm{Cd}$ concentration in the soil (around $0.1 \mathrm{mg} \mathrm{kg}{ }^{-1}$ ). $\mathrm{Cd}$ concentrations in shoots increased greatly with $\mathrm{Cd}$ addition (Table 4). Application of $\mathrm{Zn}$ at 2 and $10 \mathrm{mg} \mathrm{kg}^{-1}$ did not have significant effects on $\mathrm{Cd}$ concentrations in shoots. With 15 and $30 \mathrm{mg} \mathrm{Cd} \mathrm{kg}{ }^{-1}, 100$ and $1000 \mathrm{mg} \mathrm{Zn} \mathrm{kg}^{-1}$ reduced shoot $\mathrm{Cd}$ concentrations and with $50 \mathrm{mg} \mathrm{Cd} \mathrm{kg}^{-1}$ there was a reduction by $1000 \mathrm{mg} \mathrm{Zn} \mathrm{kg}^{-1}$.

Table 4. Cadmium concentrations $\left(\mathrm{mg} \mathrm{kg}^{-1}\right)$ in shoots of winter wheat plants grown in pot culture at different levels of $\mathrm{Zn}$ and $\mathrm{Cd}$ additions.

\begin{tabular}{llllll}
\hline $\begin{array}{c}\text { Cd addition } \\
\mathrm{mg} \mathrm{kg}^{-1} \text { soil }\end{array}$ & \multicolumn{5}{c}{ Zn addition $\left(\mathrm{mg} \mathrm{kg}^{-1}\right.$ soil) } \\
\hline & 0 & 2 & 10 & 100 & 1000 \\
\hline 0 & n.d. & n.d. & n.d. & n.d. & n.d. \\
15 & $39.8 \pm 2.07$ & $40.1 \pm 1.56$ & $39.4 \pm 1.60$ & $28.1 \pm 0.65$ & $22.5 \pm 0.37$ \\
30 & $70.1 \pm 2.67$ & $69.8 \pm 4.54$ & $64.8 \pm 4.00$ & $54.3 \pm 3.64$ & $37.3 \pm 2.72$ \\
50 & $76.4 \pm 1.68$ & $77.6 \pm 1.17$ & $72.7 \pm 1.85$ & $74.6 \pm 6.33$ & $41.5 \pm 3.44$ \\
\hline \multicolumn{5}{c}{ Analysis of variance } \\
\hline $\mathrm{Cd}$ & \multicolumn{5}{c}{$\mathrm{P}<0.001$} \\
$\mathrm{Zn}$ & & $\mathrm{P}<0.001$ & \\
$\mathrm{Cd} \times \mathrm{Zn}$ & & $\mathrm{P}=0.007$ & \\
\hline
\end{tabular}

* Not detectable.

Cd concentrations in roots were much higher than in shoots (Tables $4 \& 5$ ), and also increased with $\mathrm{Cd}$ addition. With 15 and $30 \mathrm{mg} \mathrm{Cd} \mathrm{kg}^{-1}, \mathrm{Zn}$ applications at 2 and 10 
$\mathrm{mg} \mathrm{kg}^{-1}$ did not significantly affect root $\mathrm{Cd}$ concentrations; while $\mathrm{Zn}$ applications of 100 and $1000 \mathrm{mg} \mathrm{kg}^{-1}$ reduced Cd concentrations. With $50 \mathrm{mg} \mathrm{Cd} \mathrm{kg}^{-1}$, applications of 10 to $1000 \mathrm{mg} \mathrm{Zn} \mathrm{kg}^{-1}$ reduced root $\mathrm{Cd}$ concentrations.

Zinc concentrations in shoots increased significantly with increasing $\mathrm{Zn}$ applications (Table 6). With low levels of $\mathrm{Zn}$, Cd addition had little effect on shoot $\mathrm{Zn}$ concentrations, but with 100 and $1000 \mathrm{mg} \mathrm{Zn} \mathrm{kg}^{-1}, \mathrm{Zn}$ concentrations in shoots tended to decrease with increasing $\mathrm{Cd}$ addition. This was most pronounced with $1000 \mathrm{mg} \mathrm{Zn} \mathrm{kg}^{-1}$. Zn concentrations in roots showed a different pattern of changes from concentrations in shoots (Table 7). With 0 and $100 \mathrm{mg} \mathrm{Zn} \mathrm{kg}{ }^{-1}$, there was no consistent change in root $\mathrm{Zn}$ concentration with changing $\mathrm{Cd}$ additions, but with1000 $\mathrm{mg} \mathrm{Zn} \mathrm{kg}^{-1}, \mathrm{Cd}$ addition significantly reduced $\mathrm{Zn}$ concentrations in roots.

Table 5. Cadmium concentrations $\left(\mathrm{mg} \mathrm{kg}^{-1}\right)$ in roots of winter wheat grown in pot culture at different levels of $\mathrm{Zn}$ and $\mathrm{Cd}$ additions.

\begin{tabular}{|c|c|c|c|c|c|}
\hline \multirow{2}{*}{$\begin{array}{l}\text { Cd addition } \\
\mathrm{mg} \mathrm{kg}^{-1} \text { soil }\end{array}$} & \multicolumn{5}{|c|}{$\mathrm{Zn}$ addition ( $\mathrm{mg} \mathrm{kg}^{-1}$ soil) } \\
\hline & 0 & 2 & 10 & 100 & 1000 \\
\hline 0 & $1.2 \pm 0.2$ & $1.7 \pm 0.3$ & $0.6 \pm 0.1$ & $4.7 \pm 0.8$ & $2.8 \pm 1.7$ \\
\hline 15 & $195 \pm 1.9$ & $221 \pm 15.9$ & $185 \pm 1.1$ & $150 \pm 5.3$ & $121 \pm 4.4$ \\
\hline 30 & $419 \pm 1.4$ & $389 \pm 8.1$ & $392 \pm 6.1$ & $281 \pm 5.0$ & $251 \pm 13.8$ \\
\hline 50 & $579 \pm 20.4$ & $666 \pm 60.7$ & $479 \pm 35.6$ & $495 \pm 35.8$ & $282 \pm 12.3$ \\
\hline & \multicolumn{5}{|c|}{ Analysis of variance } \\
\hline $\mathrm{Cd}$ & \multicolumn{5}{|c|}{$\mathrm{P}<0.001$} \\
\hline $\mathrm{Zn}$ & \multicolumn{5}{|c|}{$\mathrm{P}<0.001$} \\
\hline $\mathrm{Cd} \times \mathrm{Zn}$ & \multicolumn{5}{|c|}{$\mathrm{P}<0.001$} \\
\hline
\end{tabular}

Significant $\mathrm{Zn}-\mathrm{Cd}$ interactions were evident in this experiment in terms of both plant biomass and $\mathrm{Zn} / \mathrm{Cd}$ concentrations in plant tissues. In this study, $\mathrm{Zn}$ application did not improve plant growth in the absence of $\mathrm{Cd}$ application, showing that the soil used is not $\mathrm{Zn}$-deficient. This result is consistent with some previous studies, which showed that $\mathrm{Zn}$ did not have inhibitory effects on plant uptake of $\mathrm{Cd}$ (Nan et al. 2002), and may relate to the use of soils that are not deficient in $\mathrm{Zn}$. It has been suggested that one option to reduce $\mathrm{Cd}$ accumulation in wheat grains was to effectively improve plant $\mathrm{Zn}$ nutrition via soil or foliar applications (Clarke et al. 1997; Grant et al. 1998; Cakmak et al. 2000). However, results from this study demonstrated that the inhibitory effects of the higher levels of $\mathrm{Zn}$ application, designed to minimize plant uptake of $\mathrm{Cd}$, might have some limitations depending on the actual $\mathrm{Zn}$ nutritional status of the plant. Although increase in $\mathrm{Zn}$ application to 100 and $1000 \mathrm{mg} \mathrm{kg}^{-1}$ significantly reduced $\mathrm{Cd}$ concentrations in plant tissues, the reduction in $\mathrm{Cd}$ concentration did not actually improve plant growth (no biomass gain). This could be due to the fact that $\mathrm{Zn}$ application at $100 \mathrm{mg} \mathrm{kg}^{-1}$ 
started to have phytotoxicity to wheat plants (Table 2). However, the interactions between $\mathrm{Zn}$ and $\mathrm{Cd}$ observed in this study may be complicated further by the companion anion applied to the soil with $\mathrm{Zn}, \mathrm{SO}_{4}{ }^{2-}$, which was shown to possibly increase plant uptake of Cd (Zhao et al. 2003).

Table 6. Zinc concentrations $\left(\mathrm{mg} \mathrm{kg}^{-1}\right)$ in shoots of winter wheat grown in pot culture at different levels of $\mathrm{Zn}$ and $\mathrm{Cd}$ additions.

\begin{tabular}{llllll}
\hline $\begin{array}{l}\text { Cd addition } \\
\mathrm{mg} \mathrm{kg}^{-1} \text { soil }\end{array}$ & \multicolumn{5}{c}{ Zn addition $\left(\mathrm{mg} \mathrm{kg}^{-1}\right.$ soil) } \\
\hline & 0 & 2 & 10 & 100 & 1000 \\
\hline 0 & $104 \pm 5.1$ & $115 \pm 2.7$ & $147 \pm 3.8$ & $397 \pm 16.0$ & $1950 \pm 61$ \\
15 & $103 \pm 5.4$ & $121 \pm 5.4$ & $159 \pm 6.2$ & $455 \pm 7.7$ & $1730 \pm 31$ \\
30 & $102 \pm 5.4$ & $109 \pm 2.1$ & $142 \pm 12.1$ & $350 \pm 20.4$ & $1235 \pm 85$ \\
50 & $97 \pm 4.6$ & $107 \pm 9.2$ & $139 \pm 4.4$ & $342 \pm 15.7$ & $708 \pm 55$ \\
\hline \multicolumn{5}{c}{ Analysis of variance } \\
\hline $\mathrm{Cd}$ & $\mathrm{P}<0.001$ \\
$\mathrm{Zn}$ & \multicolumn{5}{c}{$\mathrm{P}<0.001$} \\
$\mathrm{Cd} \times \mathrm{Zn}$ & $\mathrm{P}<0.001$ \\
\hline
\end{tabular}

Table 7. Zinc concentrations $\left(\mathrm{mg} \mathrm{kg}^{-1}\right)$ in roots of winter wheat grown in pot culture at different levels of $\mathrm{Zn}$ and $\mathrm{Cd}$ additions.

\begin{tabular}{|c|c|c|c|c|c|}
\hline $\mathrm{Cd}$ addition & \multicolumn{5}{|c|}{$\mathrm{Zn}$ addition ( $\mathrm{mg} \mathrm{kg}^{-1}$ soil) } \\
\hline & 0 & 2 & 10 & 100 & 1000 \\
\hline 0 & $50.8 \pm 3.1$ & $75.6 \pm 6.1$ & $98.4 \pm 12.3$ & $563 \pm 46.6$ & $5409 \pm 375$ \\
\hline 15 & $66.3 \pm 3.9$ & $64.2 \pm 5.8$ & $186.7 \pm 3.5$ & $694 \pm 13.0$ & $4338 \pm 338$ \\
\hline 30 & $98.4 \pm 8.8$ & $96.4 \pm 14.2$ & $135.9 \pm 12$ & $5189 \pm 4.9$ & $3275 \pm 120$ \\
\hline 50 & $68.6 \pm 2.5$ & $82.5 \pm 16.9$ & $145.9 \pm 9.2$ & $673 \pm 5.1$ & $2220 \pm 410$ \\
\hline & \multicolumn{5}{|c|}{ Analysis of variance } \\
\hline $\mathrm{Cd}$ & \multicolumn{5}{|c|}{$\mathrm{P}<0.001$} \\
\hline $\mathrm{Zn}$ & \multicolumn{5}{|c|}{$\mathbf{P}<0.001$} \\
\hline $\mathrm{Cd} \times \mathrm{Zn}$ & \multicolumn{5}{|c|}{$\mathbf{P}<0.001$} \\
\hline
\end{tabular}

The amounts of $\mathrm{Cd}$ added to the soil in this experiment were relatively high than those in most agricultural soils, but, high concentration of $\mathrm{Cd}$ in arable soils do occur in areas in vicinity of mining and smelting sites in China. For example soils in an area near a smelter in Nanning, Guangxi Province in China, have average $\mathrm{Cd}$ concentrations up to $22 \mathrm{mg} \mathrm{kg}-1$, yet local people still grow vegetables for their own consumption (Cui Yujing, personal communication). Additions of $\mathrm{Cd}$ reduced plant growth significantly except at the highest $\mathrm{Zn}$ application in the present study. At the highest $\mathrm{Zn}$ application, plant biomass was only $10 \%$ of that for the control plants and $\mathrm{Zn}$ toxicity, not $\mathrm{Cd}$ toxicity, may be the dominant factor affecting plant 
growth. Competitive effects of $\mathrm{Cd}$ on $\mathrm{Zn}$ accumulation by wheat plants were also evident, particularly at the highest $\mathrm{Zn}$ application (Table 6), but this competition did not release any stress from soil $\mathrm{Zn}$ contamination. Soil and plant phosphorus status may also affect plant uptake of Cd (Grant and Bailey 1997; Yang et al. 1999; Maier et al. 2002). In this study, the soil is high in $P$ (data not shown). High phosphorus may also alter the interactions between $\mathrm{Zn}$ and $\mathrm{Cd}$, which has not been studied extensively so far.

In summary, the results show that attempts to ameliorate $\mathrm{Cd}$ toxicity by applying $\mathrm{Zn}$ fertilizer may be complicated by individual soil types and nutrient status (e.g. P). The inhibitory effects of soil $\mathrm{Zn}$ on $\mathrm{Cd}$ concentrations in plant tissues occurred only at toxic $\mathrm{Zn}$ levels, but this inhibition did not improve plant growth suggesting that $\mathrm{Zn}$ concentration became the dominant factor controlling plant growth.

Acknowledgments. Y-GZ is supported by the "Hundred Talent Program" of the Chinese Academy of Sciences. Financial support from Natural Science Foundation of China is much appreciated (Project number: 40225002). This paper was presented at the First International Conference on Pollution Eco-Chemistry \& Ecological Processes, Shenyang, China, August 26-31 2002.

\section{REFERENCES}

Basta NT, Raun WR, Gavi F (1998) Wheat grain cadmium under long-term fertilization and continuous winter wheat production. Better Crops 82: 14-15

Cakmak I, Welch RM, Erenoglu B, Römheld V, Novell WA, Kochian V (2000) Influence of varied $\mathrm{Zn}$ supply on re-translocation of $\mathrm{Cd}\left({ }^{109} \mathrm{Cd}\right)$ and $\mathrm{Rb}\left({ }^{86} \mathrm{Rb}\right)$ applied on mature leaf of durum wheat seedlings. Plant Soil 219: 279-284

Choudhary M, Baily LD, Grant CA (1994) Effect of zinc on cadmium concentration in tissue of durum wheat. Can. J Plant Sci 74: 549-552

Clarke JM, Leisle D, De Pauw RM, Thiessen LL (1997) Registration of five pairs of durum wheat genetic stocks near-isogenic for cadmium concentration. Crop Sci 37: 297- 297

Grant CA, Bailey LD (1998) Nitrogen, phosphorus and zinc management effects on grain yield and cadmium concentration in two cultivars of durum wheat. Cana J Plant Sci 78: 63-70

Grant CA, Baily LD (1997) Effects of phosphorus and zinc fertilizer management effects on cadmium accumulation in flaxseed. J Sci Food Agric 73: 307-314

Jin T, Nordberg M, Frech W, Dumont X, Bernard A, Ye TT, Kong Q, Wang Z, Li P, Lundstrom N, Li Y, Nordberg GF (2002) Cadmium biomonitoring and renal dysfunction among a population environmentally exposed to cadmium from smelting in China (ChinaCad). BioMetals 15: 397-410 
Jones KC, Johnston AE (1989) Cadmium in cereal grain and herbage from long-term experimental plots at Rothamsted, UK. Environ Pollut 57: 199-216

Mair NA, McLaughlin MJ, Heap M, Butt M, Smart MK (2002) Effects of nitrogen Source and calcium lime on soil $\mathrm{pH}$ and potato yield, leaf chemical composition, and tuber cadmium concentrations. J Plant Nutrition 25: 523-544

McLaughlin MJ, Singh BR (1999) Cadmium in soil and plants: A global perspective. In: McLaughlin MJ and Singh BR (ed) Cadmium in soils and Plants, Kluwer Academic Publishers, Dordrecht, The Netherlands, p13-21

Nan ZR, Li JJ, Zhang JM, Chen GD (2002) Cadmium and zinc interactions and their transfer in soil-plant system under actual field conditions. Sci Tot Environ 285: $187-195$

Oliver DP, Hannam R, Tiller KG, Wilhelm NS, Merry RH, Cozen GD (1994) The effects of zinc fertilization on cadmium concentration in wheat grain. J Environ Qual 23: 705-711

White MC, Chaney RL (1980) Zinc, Cd and Mn uptake by soybean from two zn-and Cd-amended coastal plain soils. Soil Sci Soc Am J 44: 308-313

Williams CH, David DJ (1976) The accumulation in soil of cadmium residues from phosphate fertilizer and their effect on the cadmium content of plants. Soil Sci 121:86-93

Yang ZM, Zheng SJ, Hu AT (1999) Effects of different levels of P supply and $\mathrm{pH}$ on the content of cadmium in corn and wheat plants. J Nanjing Agr Univ (in Chinese) 22: 46-50

Zhao ZQ, Zhu YG, Li HY, Smith SE, Smith FA (2003) Effects of forms and rates of potassium fertilizers on cadmium uptake by two cultivars of spring wheat (Triticum aestivum, L.). Environ Int 1073:1-6 